\title{
Coastal Bermudagrass, Bahiagrass, and Native Range Simulation at Diverse Sites in Texas
}

\author{
J. R. Kiniry,* B. L. Burson, G. W. Evers, J. R. Williams, H. Sanchez, C. Wade, J. W. Featherston, and J. Greenwade
}

\begin{abstract}
Effective comparisons of natural grasslands and improved pasture require a robust model for plant growth, soil water balance, runoff, soil erosion, and climatic impacts. Our first objective was to develop plant parameters in the field that enabled the ALMANAC model to simulate growth of coastal bermudagrass [Cynodon dactylon $(\mathrm{L}$.) Pers.]. Pensacola bahiagrass (Paspalum notatum Flïgge var saurae Parodi), and some common native, warm-season grasses. Parameters included leaf area, light interception, biomass growth, and nitrogen concentration. The maximum leaf area index values of coastal bermudagrass and bahiagrass were near 2.2. Those for native grasses other than switchgrass (Panicum virgatum L.) were much less. Mean values for light extinction coefficient ranged from 0.7 to 2.1. Radiation use efficiency values for four of the five measured grass species were between 1.0 and $2.0 \mathrm{~g} \mathrm{MJ}^{-1}$. Grass [N] values showed similar patterns of seasonal change among species. Our second objective was to use these grass parameters to simulate biomass production of coastal bermudagrass, bahiagrass, and some native grasses on representative soils in several counties in a number of regions of Texas. Counties and soils that were simulated represented a diversity of sites in Texas where improved grasses and native grasses are grown. The ALMANAC model reasonably simulated biomass means and SDs for native grasses, coastal bermudagrass, and bahiagrass. The model is a realistic tool to simulate effects of soil type and weather on native and improved grass productivity on such diverse sites.
\end{abstract}

A S NATURAL GRASSLANDS are converted to or from improved pasture or croplands, the change in ground cover can have large effects on the soil nutrient balance, soil erosion, and water quality in adjacent waterways. Effective, efficient evaluation of the impact of such changes in vegetative cover requires a robust model for plant growth, the soil water balance, runoff, soil erosion, and climatic impacts.

There are many possible applications of such a model. It could be used to compare mean productivity and stability of productivity across years for native grass range sites and for improved pastures. It also could simulate environmental impacts of changing plant cover. These impacts include changes in soil erosion and water quality. Model simulations could help optimize livestock

J.R. Kiniry, USDA-ARS, Grassland, Soil and Water Res. Lab., 808 East Blackland Rd., Temple, TX 76513; B.L. Burson, USDA-ARS, 430 Heep Center, Texas A\&M Univ. College Station, TX 77843-2474; G.W. Evers, Texas A\&M Univ. Agric. Res. and Ext. Center, P.O. Box E, Overton, TX 75684; J.R. Williams, Texas Agric. Exp. Stn., 808 E. Blackland Rd., Temple, TX 76513; H. Sanchez, USDA-NRCS, P.O. Box 6567, Fort Worth, TX 76115; C. Wade, USDA-NRCS, 2301 N. Travis Ave., P.O. Box 1027, Cameron, TX 76520-1027; and J. Featherston and J. Greenwade, USDA-NRCS, 101 S. Main, Temple, TX 76501-7682. Received 13 Apr. 2006. *Corresponding author (jkiniry@spa.ars.usda.gov).

Published in Agron. J. 99:450-461 (2007).

Modeling

doi:10.2134/agronj2006.0119

(C) American Society of Agronomy

677 S. Segoe Rd., Madison, WI 53711 USA

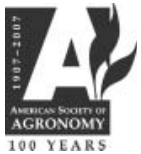

stocking rates and applied nutrients for native and improved grasses on different soils with varying rainfall amounts. Likewise, the responses of soil erosion and forage productivity to different grazing intensities could be simulated.

Ideally, such a model would have sufficient detail to simulate several plant species, soils, and climatic conditions without excessive input requirements. The model should be able to simulate improved grasses and common native grasses. The required plant parameters should be simple enough to be readily derived from published studies in conjunction with measurements that can be obtained without an inordinate amount of time and effort in field experiments. The model should have processbased components to simulate leaf area growth, biomass production, and nutrient uptake. In addition, the required soils data should be readily available, and there should be data sets with sufficient detail available for validating grass production simulations.

There has been a diversity of simulation models developed for grasses. These models include the SPUR (Simulation of Production and Utilization on Rangelands) model (Wight and Skiles, 1987; MacNeil et al., 1985; Stout, 1994) and the ELM (Ecosystem Level Model) (Innis, 1978). In addition, Overman et al. (1988, 1989) described two simple models to simulate coastal bermudagrass production with only three or four parameters that are fitted for each new location. More recently, Rymph et al. (2004) adapted the CROPGRO model (Boote et al., 1998) to simulate bahiagrass.

A more general model, called ALMANAC (Agricultural Land Management Alternative with Numerical Assessment Criteria), simulates a diversity of grass species as well as crops and interspecies competition (Kiniry et al., 1992). This model meets all the above-mentioned criteria and has great potential for the listed applications. It is process based and can simulate one or several competing species. It simulates plant growth using independently derived parameters, with no recalibration among sites. The model includes components for the water balance, nutrient balance, and interception of solar radiation by competing plant species. Although some subroutines and functions from the EPIC (Erosion Productivity Impact Calculator) model (Williams et al., 1984) are included, the plant growth simulation is more detailed (Kiniry, 2006). Daily values for maximum and minimum temperatures, precipitation, and incident solar radiation are required. Soil inputs are readily available from published USDA-ARS soil surveys.

The ALMANAC model is a valuable tool to simulate diverse cropping systems and diverse rangelands in the

Abbreviations: IPAR, intercepted photosynthetically active radiation; $k$, light extinction coefficient for Beer's law; LAI, leaf area index; LAImx, maximum leaf area index; $[\mathrm{N}]$, nitrogen concentrations; RLAD, rate of LAI decline; RUE, radiation use efficiency. 
USA (Kiniry et al., 1996, 1997, 2004, and 2005; Kiniry and Bockholt, 1998; Yun et al., 2001). Recently, ALMANAC was shown to reasonably simulate native grass productivity on 20 soils at diverse sites in Texas (Kiniry et al., 2002).

Although that study demonstrated the usefulness of this model for native range simulation, it did not address common improved grasses, such as coastal bermudagrass or bahiagrass. Often, such improved grasses have replaced native grass species. Realistic simulation of these two improved grasses in pastures will offer added dimensions to the possible applications of this model. If ALMANAC can accurately simulate such improved pastures and the native rangelands, the model could be a valuable tool for comparing these grass production systems on several soils and with variable rainfall amounts.

For the first part of our study, we developed plant parameters that allow ALMANAC to simulate coastal bermudagrass, bahiagrass, and three native, warmseason grasses that were not included in the previous study (Kiniry et al., 1999). Additional field data were collected on two of the grasses that were in the previous study: sideoats grama (Bouteloua curtipendula (Michaux) Torrey) and switchgrass. This allowed us to test the stability of the parameters for those two species with independent data. Measurements were taken at three field sites in Texas for multiple years. To derive these plant parameters, we needed nearly nonlimiting environmental conditions with deep soils, adequate soil nutrients, and adequate soil moisture. Although typical rangeland conditions often have drought or nutrient limitations, when developing simulation model parameters, nearoptimum conditions allow for simulation of yield when sufficient nutrients and soil water are available. Likewise, realistic simulation of the water balance and nutrient balance provides accurate simulations in stress conditions. This modeling approach allows for direct model application with appropriate soil, water, and management inputs without recalibration at new sites.

In the second part of this study, the parameters we derived were used to simulate yields of native and improved grasses as reported by USDA-NRCS. This extended the previous test results (Kiniry et al., 2002) to areas with improved and native grasses. This allowed direct comparisons of the simulated yields of native and improved species with the same soils and with the same weather. We simulated biomass production of improved and native grasses on representative soils in several counties in Texas. Using published USDA-NRCS site productivity estimates (based on 3-5 yr of sampling), we evaluated the ability of the ALMANAC model to simulate productivity of coastal bermudagrass, bahiagrass, and native range. The grass yields reported by USDA-NRCS are currently called "ecological site" productivity, whereas in this paper we refer to them as "native range" productivity.

Important plant parameters included maximum leaf area index (LAImx), light extinction coefficient $(k)$ for Beer's law (Monsi and Saeki, 1953), radiation use efficiency (RUE), and optimum plant $\mathrm{N}$ concentrations during the season. Reported values for LAImx for bahiagrass and bermudagrass sometimes exceeded 6.0. Agata (1985a, b) reported that bahiagrass LAI in Japan increased to 7.5 and 8.5. Morgan and Brown (1983a, b) reported that coastal bermudagrass in Georgia had LAI values as large as 6 to 10. In contrast to these studies, Pedreira and Brown (1996) reported LAI values of 2.17 and 2.21 in late July and early August in Georgia for Pensacola bahiagrass. Although not as extensively reported as LAI, $k$ values had a mean of 0.36 for bahiagrass in Japan (Agata, 1985a), and coastal bermudagrass, with 12 data points in Georgia, had a mean $k$ of 1.00 (Morgan and Brown, 1983a).

Biomass growth is simulated as a function of intercepted solar radiation. The slope of biomass/intercepted photosynthetically active radiation (IPAR) is the RUE. Grass RUE can vary widely, from $1.8 \mathrm{~g}$ of biomass per MJ of IPAR for sideoats grama to 4.7 for switchgrass (Kiniry et al., 1999). Values for RUE have also been determined for honey mesquite (Prosopis glandulosa Torr. var glandulosa) and eastern red cedar (Juniperus virginia L.) (Kiniry, 1998) and johnsongrass (Sorghum halepense (L.) Pers.) (Kiniry, 1994).

Accurate values for optimum $\mathrm{N}$ concentrations of the whole plant enable accurate simulation of the plant nutrient balance. For each grass species simulated, ALMANAC requires optimum $\mathrm{N}$ concentrations for early season- and mid-season growth and at the end of the season. Concentrations of $\mathrm{N}$ in coastal bermudagrass and bahiagrass decrease from greater than $30 \mathrm{~g} \mathrm{~kg}^{-1}$ early in the season to less than $20 \mathrm{~g} \mathrm{~kg}^{-1}$ late in growth. Coastal bermudagrass in Georgia had mean $\mathrm{N}$ concentrations of 35.5 at $1 \mathrm{wk}$ after harvest, 32.3 at $2 \mathrm{wk}$ after harvest, 27.5 at $4 \mathrm{wk}$ after harvest, and 18.7 at $8 \mathrm{wk}$ after harvest (Monson and Burton, 1982). Although coastal bermudagrass $\mathrm{N}$ concentrations have been reported to be greater than for Pensacola bahiagrass (Wilkinson and Langdale, 1974), bermudagrass $\mathrm{N}$ does not always exceed that of bahiagrass. Bahiagrass $\mathrm{N}$ values of 16.0 to 19.6 have been reported in Florida (Adjei et al., 1980) and Georgia (Beaty et al., 1980), whereas bermudagrass hybrids have had $\mathrm{N}$ concentrations of 17.9 to 20.9 in Florida (Pedreira et al., 1999) and 20.2 in Georgia (Burton and DeVane, 1952). Concentrations of $\mathrm{N}$ for Pensacola bahiagrass were $70 \%$ of that for coastal bermudagrass for the top three applied $\mathrm{N}$ levels in Alabama (Ashley et al., 1965). In Florida, Tifton 85 bermudagrass had $22 \mathrm{~g} \mathrm{~kg}^{-1} \mathrm{~N}$, and Pensacola bermudagrass had 20 (Johnson et al., 2001). However, in another study in Florida, Pensacola bahiagrass had $32 \mathrm{~g} \mathrm{~kg}^{-1} \mathrm{~N}$ in late March, $22.4 \mathrm{~g} \mathrm{~kg}^{-1} \mathrm{~N}$ in mid June, and $19.2 \mathrm{~g} \mathrm{~kg}^{-1} \mathrm{~N}$ in mid September, whereas Coastcross bermudagrass had $28.8 \mathrm{~g} \mathrm{~kg}^{-1} \mathrm{~N}, 22.2 \mathrm{~g} \mathrm{~kg}^{-1} \mathrm{~N}$, and $20.8 \mathrm{~g} \mathrm{~kg}^{-1} \mathrm{~N}$ on these harvest dates (Mislevy and Everett, 1981). When Pensacola bahiagrass was grown in a greenhouse, the $\mathrm{N}$ concentration in the leaves was 21 from $10 \mathrm{~d}$ after leaf emergence until $30 \mathrm{~d}$ later and then dropped to 5 by $55 \mathrm{~d}$ after leaf emergence (Sampaio et al., 1976).

Therefore, although there are scattered references with some parameter values of interest for these grasses, there has not been a unified study using common experimental techniques and the same or similar sites for 
these two improved grasses along with these common native grasses. Such results will provide more reliable parameters for simulations useful in comparing native and improved grass systems.

\section{MATERIALS AND METHODS}

\section{Parameter Derivation}

Studies to derive grass parameters for modeling were performed at three sites. One was at the Grassland, Soil and Water Research Laboratory near Temple, Texas $\left(32^{\circ} 4^{\prime \prime} \mathrm{N}, 97^{\circ} 10^{\prime \prime} \mathrm{W}\right.$; $191 \mathrm{~m}$ a.s.l.) on Houston Black clay (fine, smectitic, thermic Udic Haplusterts). The other two sites were on Crockett fine sandy loams (fine, smectitic, thermic Udertic Paleustalfs), one near Wills Point, TX $\left(32^{\circ} 49^{\prime \prime} \mathrm{N}, 96^{\circ} 5^{\prime \prime} \mathrm{W} ; 137 \mathrm{~m}\right.$ a.s.l) and one near Maysfield, TX ( $30^{\circ} 53^{\prime \prime} \mathrm{N}, 96^{\circ} 48^{\prime \prime} \mathrm{W} ; 107 \mathrm{~m}$ a.s.l.). At the Temple site, we established plots of six $\mathrm{C}_{4}$ grass species. All plots were 5 by $5 \mathrm{~m}$ arranged in a randomized complete block of four replicates. We planted seeds of Alamo switchgrass, Haskell sideoats grama, Aldous little bluestem (Schizachyrgium scoparium (Michaux) Nash), and an unselected genotype of blue grama (Bouteloua gracilis (H.B.K.) Lag. ex Steud.) in January 1998 and took measurements on them in subsequent growing seasons. Also in 1998, plots of Nebraska 609 buffalograss (Buchloë dactyloides (Nutt.) Englem.) were established from sod, and plots of coastal bermudagrass were established from sprigs in each replication. These plots were also measured in subsequent seasons.

At the Wills Point site and the Maysfield site, fences were built to exclude cattle from the study areas. At the Wills Point site in 2003, within an established pasture of bahiagrass, the fenced area was 23 by $11 \mathrm{~m}$. The area was managed to assure bahiagrass was the dominant grass and measured in the seasons thereafter. This involved mowing at critical dates, herbicide applications, and fertilizing to assure no nutrient deficiency under the management practices used. At the Maysfield site in 2004, the fenced area was in an established pasture area with one half dominated by bahiagrass and one half dominated by coastal bermudagrass. This fenced area was 15 by $10 \mathrm{~m}$. Mowing and herbicide applications were used to assure these two grass species were dominant. These plots were measured each season thereafter.

Bahiagrass plants at Wills Point and Maysfield were the Pensacola cultivar. The bahiagrass at both sites were initially thought to be planted with the Pensacola, but this could not be definitively determined by plant phenotype. Pensacola is a diploid with $2 n=2 \mathrm{x}=20$ chromosomes, whereas all other bahiagrass cultivars that were commercially available when these pastures were established are tetraploids with $2 n=4 \mathrm{x}=$ 40 chromosomes. To establish the cultivar in both pastures, the ploidy level of plants collected from both locations was determined using flow cytometry. The ploidy level of each plant taken from both pastures was determined by comparing its $2 \mathrm{C}$ peak with the $2 \mathrm{C}$ peak of Argentine bahiagrass. All bahiagrass plants collected from the two sites had one half of the DNA content as the internal standard Argentine bahiagrass. Because Argentine is a tetraploid, this indicates the all the plants dug from the research sites were diploids. Therefore, both of these pastures apparently consisted of a diploid bahiagrass. Because they were established when Pensacola was the only commercially available diploid bahiagrass cultivar, both pastures were Pensacola bahiagrass.

Annual rainfall sums at Temple from 1998 to 2005 were 1043, 461, 902, 1029, 727, 622, 1067, and $614 \mathrm{~mm}$. At Wills Point for 2003-2005, rainfall sums were 709, 1222, and $591 \mathrm{~mm}$. For Maysfield for 2004 and 2005, sums were 1479 and $699 \mathrm{~mm}$.
Plots at Temple and Wills Point were fertilized each spring of each measurement year (Table 1). Plots at Maysfield were not fertilized, and residual $\mathrm{N}$ was relied on to avoid loss of the bahiagrass plots to coastal bermudagrass encroachment. At Temple in 1998 to 2002, all grasses were burned in February. Temple plots were mowed in March in 2003, burned in December 2003, and mowed in March 2005.

At the Temple site, the fraction of intercepted PAR (FIPAR) was measured on three dates in 1998, on six dates in 1999, on four dates in 2000, on four dates in 2003, and on two dates in 2005. At Wills Point, there were six sampling dates in 2003, three dates in 2004, and six dates in 2005. At Maysfield, there were two sampling dates in 2004 and five dates in 2005. On each sampling date, there were at least five measurements of PAR above the canopy, at least 10 below the leaf canopy at different positions, and at least five more above, in rapid succession. There were three sets of these light interception readings within each replication. PAR was measured with a 0.8-m-long Sunfleck Ceptometer PAR light bar sensor (Decagon Devices, Pullman, WA) while moving the sensor across the plot and avoiding harvested areas. Light measurements were taken between 10 AM and 2 PM local time. Measurements taken several times during a day indicated that FIPAR measurements in this time interval were within $2 \%$ of the weighted daily mean FIPAR. The weights were the incident PAR during each measurement. Our data are in agreement with Monteith's (1969) statement that "Direct measurements of radiation in crops support... that the (diurnal) variation in $k$ is usually small enough to neglect, at least over the central $8 \mathrm{~h}$ of the day when most assimilation takes place." This " $k$ " is the extinction coefficient in Beer's law (Monsi and Saeki, 1953).

The summed intercepted PAR was determined by linearly interpolating FIPAR to get daily estimates of this fraction. Daily incident PAR was calculated as $45 \%$ of the incident total solar radiation (Monteith, 1965; Meek et al., 1984) measured with standard weather stations within the plots at Temple and Wills Point and $200 \mathrm{~m}$ from the plots at Maysfield. Daily values for intercepted PAR were summed for each plot. Radiation use efficiency was determined by fitting a linear regression for aboveground dry biomass as a function of intercepted PAR. The slope was the RUE.

Dry matter (g per $\mathrm{m}^{2}$ ground area), LAI, and $\mathrm{N}$ concentration ( $\mathrm{g} \mathrm{N}$ per g dry weight) were calculated using destructive sampling. Aboveground biomass was harvested on each sampling date of each year from three randomly selected 0.25 by $0.25 \mathrm{~m}$ areas per plot. All samples were dried in a forced-air oven at $70^{\circ} \mathrm{C}$ until weight stabilized. Green leaf and stem area was estimated by measuring the area of a subsample, weighing fresh, and determining total fresh weight of green material in the entire sample. Area of the green leaves and stems of each subsample was measured with a LI-3100 leaf area meter (LiCor, Lincoln, NE). Total green area was calculated by multiplying this measured leaf and stem area by the ratio of total fresh weight of green material divided by fresh weight of the green material from subsampled tillers. Plant $\mathrm{N}$ concentra-

Table 1. Dates and amounts of ammonium nitrate application each year.

\begin{tabular}{lclc}
\hline Location & Year & Date & Ammonium nitrate applied \\
\hline & & & kg N ha $^{-1}$ \\
Temple & 1998 & 5 March & 112 \\
Temple & 1999 & 18 Feb. & 168 \\
Temple & 2000 & 1 Mar. & 168 \\
Temple & 2003 & 14 May & 56 \\
Temple & 2003 & 3 June & 60 \\
Wills Point & 2003 & 4 Feb. & 116 \\
Wills Point & 2004 & 20 Feb. & 53 \\
\hline
\end{tabular}


tions were determined by the total Kjeldahl Digest procedure by the Soil, Water, and Forage Testing Laboratory at Texas A\&M University.

Similar measurements of parameters descriptive of the growth of four native grass species were derived previously in a field experiment at Temple, TX. These included switchgrass, sideoats grama, big bluestem (Andropogon gerardii Vitman), and eastern gamagrass (Tripsacum dactyloides L.). The results of the first 3 yr of that study were published by Kiniry et al. (1999).

Simulation of light interception requires accurate description of leaf area production and decline. For this purpose, we determined the maximum LAI during each season and how LAI increased during the season. In cases with one value for LAImx much larger than in other seasons, mean LAImx values were calculated with and without the larger value. This provided some guidance for reasonable values of LAImx.

Soil water and nutrients commonly limit grass growth in Texas. ALMANAC's water balance consists of transpiration calculations predicting potential plant water use if sufficient water is present in the current rooting zone. The nutrient balance ( $\mathrm{N}$ and $\mathrm{P}$ ) also allows plants to acquire sufficient nutrients to meet the demands if adequate quantities are available in the current rooting zone. Nutrient values for the grasses were derived in the studies at the three sites, with adequate fertilizer.

\section{Data Sets for Model Evaluation}

Coastal and bahiagrass pastures are predominantly in the central and eastern counties of Texas, due to low rainfall in the western and extreme southern counties. The counties and soils in the state for this study were selected to represent the diversity of sites where coastal bermudagrass yield and native grass yield were reported by USDA-NRCS in the Web Soil Survey http://soils.usda.gov/survey) in the state (Fig. 1 and Table 2). Four of the more eastern counties also had reported yields of bahiagrass. The selected sites represent a wide range of climatic conditions. Mean annual rainfall ranged from 630 and $724 \mathrm{~mm}$ in Uvalde and Medina Counties to 1110 and $1151 \mathrm{~mm}$ in Smith and Lamar Counties.

The grass yields reported in the Web Soil Survey for range sites, coastal bermudagrass, and bahiagrass for each soil were compared with ALMANAC's mean simulated annual biomass production using $30 \mathrm{yr}$ of measured weather data. Potential annual grass biomass production values for specific soils in each county were reported in the Web Soil Survey. These reported annual production values were derived from at least $3 \mathrm{yr}$ of sampling on sites with near pristine climax condition. Although this sampling was typically done at the end of the growing season, this technique estimated total annual production. At least 10 randomly selected sample plots were measured at each site. These plots were clipped at $5 \mathrm{~cm}$ height, and the above-ground biomass was measured. The standardized NRCS procedure, to allow measurements in a diversity of regions, was to air dry samples. We assumed these samples contained 10\% moisture (Morrison, 1941). The biomass weight of all species was measured. We simulated the most common one or two reported grass species for each site when simulating annual production with ALMANAC.

Soil parameters were based on three prevalent soil series in each county (Table 3 ). Simulated annual production values were the sum of three simulated harvests during each growing season. Climate data came from a centrally located weather station in each county.

An additional data set was used for validating the simulation of coastal bermudagrass and Pensacola bahiagrass. A published study at Eagle Lake, TX (Evers, 1985) for $2 \mathrm{yr}$ had different applied N treatments. The site $\left(29^{\circ} 37^{\prime \prime} \mathrm{N}, 92^{\circ} 22^{\prime \prime} \mathrm{W}\right.$;

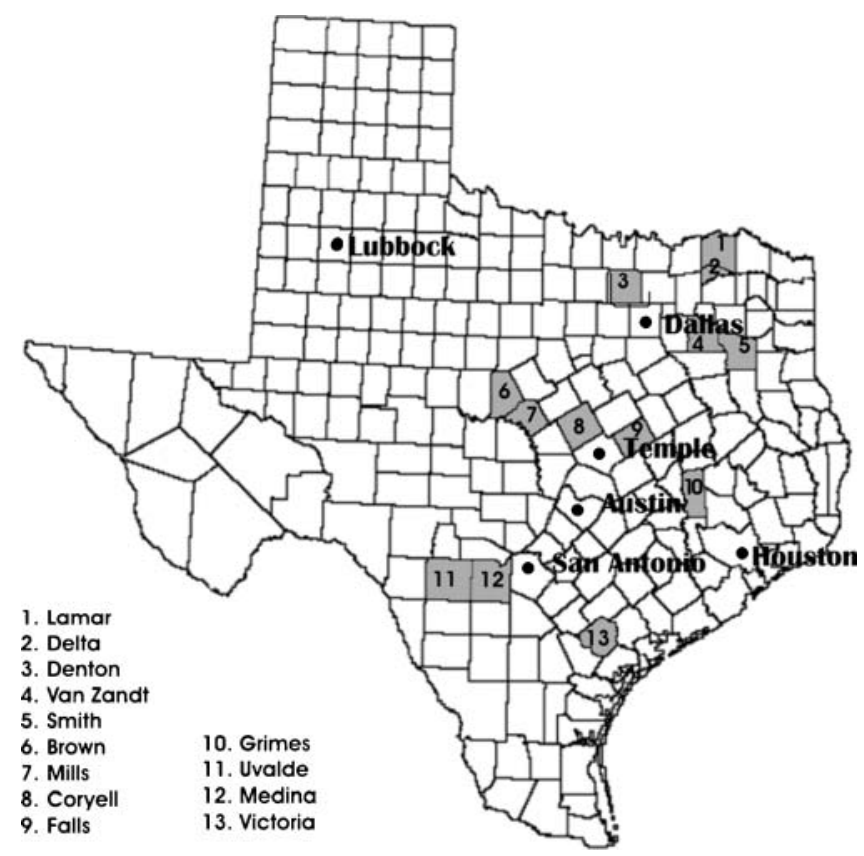

Fig. 1. Counties where coastal bermudagrass and native range were simulated. Four of these also had simulations of bahiagrass: Grimes, Lamar/Delta, Smith, and VanZandt Counties. Lamar/Delta and Brown/Mills were each reported in one soil survey, so each pair was treated as one county.

$46 \mathrm{~m}$ a.s.l.) was on a Crowley fine sandy loam (fine smectitic, thermic, Typic Albaqualfs) and had treatments ranging from 0 to $336 \mathrm{~kg} \mathrm{ha}^{-1}$ applied $\mathrm{N}$ in 1979 and 1980 . Plots were harvested monthly from May through October.

\section{Model Description}

The ALMANAC model contains components for the water balance and the nutrient balance and interception of solar radiation. The model can simulate a single plant species or several species competing for light, water, and nutrients. Daily plant growth is simulated through LAI, light interception, and a constant for converting intercepted light into biomass (RUE). The simulated LAI and biomass growth can be reduced by stresses such as nutrient deficiency, drought, or temperature extremes.

ALMANAC was designed to require only readily available inputs. Soil inputs can be derived from the USDA-NRCS National Soil Information System database http://soildatamart. nrcs.usda.gov/). Weather inputs (daily maximum and minimum temperatures, solar irradiance, and precipitation) are available from many sites.

Light interception requires simulation of leaf area production and decline. ALMANAC simulates LAI development through the season with a sigmoid curve. This describes the increase in LAI under nonstress conditions as a function of heat units. The decreases in leaf area late in the season are simulated with a factor for rate of LAI decline (RLAD). The shape of this leaf area decline function is determined from the value of RLAD. The leaf area declines linearly after flowering as heat units accumulate when the RLAD value is 1.0. Slower, nonlinear decreases occur with values less than 1.0, whereas values greater than 1.0 cause faster, nonlinear decreases.

The model simulates the LAI development based on a potential LAI for a species and a curve describing how LAI can develop during the season. Values of LAI for some representative warm-season species were from measurements on 
Table 2. Locations of data sets used in range simulations in Texas. Three stations at Evant were needed to get the 30 yr of Coryell County weather.

\begin{tabular}{|c|c|c|c|c|}
\hline Counties & Lat., long., elev. & Weather station & MLRA $\dagger$ & Mean annual precipitation: \\
\hline & & & & $\mathbf{m m}$ \\
\hline Brown and Mills & $31^{\circ} 48^{\prime} \mathrm{N}, 98^{\circ} 57^{\prime} \mathrm{W}, 420 \mathrm{~m}$ & Brownwood Municipal Airport & $85,86 A$ & 719 \\
\hline \multirow[t]{3}{*}{ Coryell } & $31^{\circ} 29^{\prime} \mathrm{N}, 98^{\circ} 09^{\prime} \mathrm{W}, 381 \mathrm{~m}$ & Evant & $85,86 A$ & 777 \\
\hline & $31^{\circ} 28^{\prime} \mathrm{N}, 98^{\circ} 10^{\prime} \mathrm{W}, 380 \mathrm{~m}$ & Evant 1SSW & & \\
\hline & $31^{\circ} 27^{\prime} \mathrm{N}, 98^{\circ} 13^{\prime} \mathrm{W}, 385 \mathrm{~m}$ & Evant 4SW & & \\
\hline Denton & $33^{\circ} 22^{\prime} \mathrm{N}, 9^{\circ} 01^{\prime} \mathrm{W}, 210 \mathrm{~m}$ & Pilot Point Isl Du Boi & $85,86 A$ & 1118 \\
\hline Falls & $31^{\circ} 20^{\prime} \mathrm{N}, 96^{\circ} 51^{\prime} \mathrm{W}, 118 \mathrm{~m}$ & Marlin 3NE & $85,86 A$ & 960 \\
\hline Grimes & $30^{\circ} 32^{\prime} \mathrm{N}, 9^{\circ} 51^{\prime} \mathrm{W}, 96 \mathrm{~m}$ & Richards & $85,86 A$ & 1156 \\
\hline Lamar and Delta & $33^{\circ} 40^{\prime} \mathrm{N}, 95^{\circ} 34^{\prime} \mathrm{W}, 165 \mathrm{~m}$ & Paris & $85,86 A$ & 1209 \\
\hline Medina & $29^{\circ} 20^{\prime} \mathrm{N}, 9^{\circ} 08^{\prime} \mathrm{W}, 267 \mathrm{~m}$ & Hondo & $85,86 A$ & 777 \\
\hline Smith & $32^{\circ} 41^{\prime} \mathrm{N}, 9^{\circ} 29^{\prime} \mathrm{W}, 134 \mathrm{~m}$ & Mineola & $85,86 A$ & 1031 \\
\hline Uvalde & $29^{\circ} 22^{\prime} \mathrm{N}, 9^{\circ} 29^{\prime} \mathrm{W}, 291 \mathrm{~m}$ & Sabinal & $85,86 A$ & 660 \\
\hline VanZandt & $32^{\circ} 42^{\prime} \mathrm{N}, 96^{\circ} 01^{\prime} \mathrm{W}, 159 \mathrm{~m}$ & Wills Point & $86 A, 87 A$ & 1196 \\
\hline Victoria & $28^{\circ} 52^{\prime} \mathrm{N}, 9^{\circ} 56^{\prime} \mathrm{W}, 35 \mathrm{~m}$ & Victoria Reg Airport & $150 \mathrm{~B}$ & 1024 \\
\hline
\end{tabular}

$\dagger$ Major Land Resource Areas.

† Average for $30 \mathrm{yr}$.

plants in field plots (Kiniry et al., 1999). Simulated potential LAI of each species was adjusted using the input plant stand (Table 4). These values were determined based on realistic plant stands for the species in common range conditions.

The model uses Beer's law (Monsi and Saeki, 1953) and the LAI to simulate light interception. The fraction of incoming solar radiation intercepted is

$$
\text { Fraction }=1.0-\exp (-k \times \mathrm{LAI})
$$

Values for $k$ (Table 5) were derived in the field as described previously (Kiniry et al., 1999).

ALMANAC simulates biomass growth with a RUE approach. The rate of biomass accumulation decline describes the decrease in RUE after anthesis for each species.

Table 3. Soils used to simulate grasses at the range sites in Texas.

\begin{tabular}{|c|c|c|c|c|}
\hline Counties & Soil series & Soil depth & PAW $\dagger$ & Runoff curve no. \\
\hline & & $-\mathbf{m}$ & 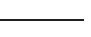 & \\
\hline \multirow{3}{*}{ Brown and Mills } & Speck & 0.46 & 0.062 & 86 \\
\hline & Frio & 2.03 & 0.329 & 75 \\
\hline & Bolar & 0.76 & 0.093 & 81 \\
\hline \multirow[t]{3}{*}{ Coryell } & Doss & 0.46 & 0.062 & 86 \\
\hline & Lewisville & 1.96 & 0.265 & 75 \\
\hline & Topsey & 2.03 & 0.288 & 82 \\
\hline \multirow[t]{3}{*}{ Denton } & Speck & 0.38 & 0.052 & 86 \\
\hline & Heiden & 2.03 & 0.254 & 75 \\
\hline & Sanger & 2.29 & 0.291 & 86 \\
\hline \multirow[t]{3}{*}{ Falls } & Ferris & 1.52 & 0.154 & 86 \\
\hline & Ships & 2.03 & 0.227 & 86 \\
\hline & Wilson & 2.03 & 0.197 & 86 \\
\hline \multirow[t]{3}{*}{ Grimes } & Zulch & 1.52 & 0.152 & 86 \\
\hline & Nahatche & 1.52 & 0.260 & 82 \\
\hline & Shiro & 0.79 & 0.081 & 82 \\
\hline \multirow{3}{*}{ Lamar and Delta } & Annona & 1.90 & 0.205 & 86 \\
\hline & Freestone & 2.03 & 0.256 & 82 \\
\hline & Crockett & 1.85 & 0.213 & 86 \\
\hline \multirow[t]{3}{*}{ Medina } & Webb & 1.98 & 0.164 & 82 \\
\hline & Victoria & 1.78 & 0.208 & 86 \\
\hline & Knippa & 2.03 & 0.138 & 82 \\
\hline \multirow[t]{3}{*}{ Uvalde } & Castroville & 2.13 & 0.381 & 75 \\
\hline & Caid & 1.93 & 0.230 & 75 \\
\hline & Knippa & 1.52 & 0.122 & 75 \\
\hline \multirow[t]{3}{*}{ VanZandt } & Bazette & 1.52 & 0.213 & 82 \\
\hline & Sandow & 1.60 & 0.256 & 82 \\
\hline & Crockett & 2.03 & 0.209 & 86 \\
\hline \multirow[t]{3}{*}{ Victoria } & Denhawken & 2.03 & 0.260 & 86 \\
\hline & Dacosta & 2.03 & 0.191 & 86 \\
\hline & Laewest & 2.03 & 0.229 & 86 \\
\hline \multirow{3}{*}{ Smith } & Cuthbert & 2.03 & 0.225 & 82 \\
\hline & Oakwood & 1.83 & 0.198 & 75 \\
\hline & Wolfpen & 1.91 & 0.170 & 69 \\
\hline
\end{tabular}

$\dagger$ PAW is the plant available water (i.e., the difference between the drained upper limit and the lower limit for the profile). Runoff curve numbers are based on soil hydrologic groups.
Soil water and nutrients commonly limit grass growth in Texas. ALMANAC's water balance consists of transpiration calculations predicting potential plant water use if sufficient water is present in the current rooting zone. The nutrient balance ( $\mathrm{N}$ and $\mathrm{P})$ also allows plants to acquire sufficient nutrients to meet the demands if adequate quantities are available in the current rooting zone. Nutrient values for the grasses were derived in the studies at the three sites, with adequate fertilizer. The simulated grass growth was reduced below potential at the range sites as nutrients became limiting.

For the ALMANAC simulations, we used maximum rooting depth values ranging from $2.2 \mathrm{~m}$ for switchgrass to $1.2 \mathrm{~m}$ for buffalograss and sideoats grama. Bahiagrass, coastal bermudagrass, big bluestem, eastern gamagrass, little bluestem, and indiangrass [Sorghastrum nutans (L.) Nash] were simulated with a value of $2.0 \mathrm{~m}$. Maximum rooting depth defines the potential depth of a plant species in the absence of a rootrestricting soil layer. Its value is critical for simulating the water balance in diverse climatic conditions and on different soils. Values from the literature indicate that coastal bermuda-

Table 4. Potential leaf area index (LAI) values based on typical grass stands at each site for wet years. Soils not listed did not have published range site yields.

\begin{tabular}{|c|c|c|c|}
\hline Counties & Soil series & Species $\dagger$ & Input potential LAIs \\
\hline \multirow[t]{3}{*}{ Brown and Mills } & Speck & LB \& SO & 1.6, 1.2 \\
\hline & Frio & BB \& LB & $1.5,1.6$ \\
\hline & Bolar & LB \& BB & $1.6,1.5$ \\
\hline \multirow[t]{3}{*}{ Coryell } & Doss & LB \& SO & $1.6,1.2$ \\
\hline & Lewisville & LB \& SW & $1.6,0.6$ \\
\hline & Topsey & LB \& SW & $1.6,0.6$ \\
\hline \multirow[t]{3}{*}{ Denton } & Speck & LB \& SO & $1.6,1.2$ \\
\hline & Heiden & LB \& BB & $1.6,1.5$ \\
\hline & Sanger & LB \& BB & $1.6,1.5$ \\
\hline \multirow{3}{*}{ Falls } & Ferris & LB \& BB & $1.6,1.2$ \\
\hline & Ships & EG \& LB & 1.6 \\
\hline & Wilson & LB \& BB & $1.6,1.5$ \\
\hline \multirow[t]{3}{*}{ Grimes } & Zulch & LB \& BB & $1.6,1.5$ \\
\hline & Nahatche & EG & 4.7 \\
\hline & Shiro & $\mathbf{L B}$ & 1.6 \\
\hline Lamar and Delta & Crockett & LB \& SO & $1.6,1.2$ \\
\hline \multirow[t]{3}{*}{ Medina } & Webb & LB \& SO & $0.4,0.3$ \\
\hline & Victoria & LB \& SO & $0.4,0.3$ \\
\hline & Knippa & LB & 0.4 \\
\hline \multirow[t]{3}{*}{ Uvalde } & Castroville & Buff & 1.5 \\
\hline & Caid & Buff & 1.5 \\
\hline & Knippa & $\mathbf{L B}$ & 1.6 \\
\hline \multirow{3}{*}{ Victoria } & Denhawken & LB \& SO & $0.4,0.3$ \\
\hline & Dacosta & LB \& Ind & $1.6,1.6$ \\
\hline & Laewest & LB \& Ind & $1.6,1.6$ \\
\hline
\end{tabular}

$\dagger$ BB, big bluestem; Buff, buffalograss; EG, eastern gamagrass; LB, little bluestem; Ind, indiangrass; SO, sideoats grama; SW, switchgrass. 
Table 5. Input parameters to simulate the grass species. Variable $k$ is the light extinction coefficient for Beer's law. $\dagger$

\begin{tabular}{llcccc}
\hline Grass & \multicolumn{1}{c}{$k$} & RUE & RLAD & RBMD & RDMX \\
\hline & & g MJ $^{-1}$ & & & m \\
Bahiagrass & $\mathbf{1 . 0}$ & $\mathbf{1 . 6}$ & $\mathbf{1 . 0}$ & $\mathbf{1 . 0}$ & $\mathbf{2 . 0}$ \\
Big bluestem & $\mathbf{0 . 3 6}$ & $\mathbf{3 . 4}$ & $\mathbf{0 . 5}$ & $\mathbf{1 0 . 0}$ & $\mathbf{2 . 0}$ \\
Buffalograss & $\mathbf{1 . 2}$ & $\mathbf{2 . 0}$ & $\mathbf{0 . 2}$ & $\mathbf{1 0 . 0}$ & $\mathbf{0 . 2}$ \\
Coastal bermuda & $\mathbf{1 . 0}$ & $\mathbf{1 . 6}$ & $\mathbf{1 . 0}$ & $\mathbf{1 . 0}$ & $\mathbf{2 . 0}$ \\
Eastern gamagrass & $\mathbf{0 . 3 1}$ & $\mathbf{5 . 0}$ & $\mathbf{0 . 2}$ & $\mathbf{1 0 . 0}$ & $\mathbf{2 . 0}$ \\
Indiangrass & $\mathbf{0 . 3 6}$ & $\mathbf{3 . 4}$ & $\mathbf{0 . 5}$ & $\mathbf{1 0 . 0}$ & $\mathbf{2 . 0}$ \\
Little bluestem & $\mathbf{0 . 3 6}$ & $\mathbf{3 . 4}$ & $\mathbf{0 . 0 1}$ & $\mathbf{0 . 5}$ & $\mathbf{2 . 0}$ \\
Sideoats grama & $\mathbf{1 . 1 2}$ & $\mathbf{1 . 8}$ & $\mathbf{0 . 1}$ & $\mathbf{1 0 . 0}$ & $\mathbf{0 . 2}$ \\
Switchgrass & $\mathbf{0 . 3 3}$ & $\mathbf{4 . 9}$ & $\mathbf{1 . 0}$ & $\mathbf{1 . 0}$ & $\mathbf{2 . 2}$
\end{tabular}

$\uparrow$ RBMD, rate of decline in biomass accumulation after anthesis; RDMX, potential maximum rooting depth; RLAD, rate of leaf area index decline after anthesis; RUE, radiation use efficiency of dry biomass $\left(\mathrm{g} \mathrm{MJ}^{-1}\right)$ of intercepted photosynthetically active radiation.

grass and bahiagrass can root to $2.0 \mathrm{~m}$ or greater. Holt and Fisher (1960) reported that coastal bermudagrass roots extend to 1.5 to $1.8 \mathrm{~m}$ in central Texas. Burton et al. (1954) reported that at the end of $1 \mathrm{yr}$ in Georgia, maximum rooting depths were $2.44 \mathrm{~m}$ for coastal bermudagrass, 1.22 for common bermudagrass, and $0.61 \mathrm{~m}$ for bahiagrass. However, by the end of $2 \mathrm{yr}$, all three grasses had roots reaching $2.44 \mathrm{~m}$. Adams et al. (1966) reported that coastal bermudagrass rooted to at least $2.0 \mathrm{~m}$ and that common bermudagrass rooted to $1.9 \mathrm{~m}$ in Georgia.

Native warm-season grasses often can root to greater than $1.5 \mathrm{~m}$ according to studies in Illinois (Sperry, 1935), Colorado (Shantz, 1911), Nebraska (Weaver, 1954), and Texas (Kiniry et al., 1999). Little bluestem rooted to $1.1 \mathrm{~m}$ depth in Illinois, 1.2 to $1.4 \mathrm{~m}$ in Nebraska, and $1.5 \mathrm{~m}$ in Colorado. Big bluestem rooted to $1.8 \mathrm{~m}$ in Illinois, 1.5 to $2.1 \mathrm{~m}$ in Nebraska, and $1.6 \mathrm{~m}$ in Texas. Sideoats grama rooted to $1.2 \mathrm{~m}$ in Nebraska and Texas. In Nebraska, indiangrass rooted to 1.5 to $1.7 \mathrm{~m}$, whereas blue grama and buffalograss rooted to $1.8 \mathrm{~m}$. Switchgrass had the deepest roots, with depths of 2.4 to $3.3 \mathrm{~m}$ in Nebraska and $2.2 \mathrm{~m}$ in Texas.

ALMANAC simulates plant development with daily heat units calculated with a base temperature and an optimum temperature. Base temperature is the same for all growth stages for a plant species. Base temperature constrains the initiation of leaf area growth and thus dry matter accumulation. Base temperature for the warm-season grasses in this study was assumed to be $12^{\circ} \mathrm{C}$, and optimum temperature was $25^{\circ} \mathrm{C}$. The input heat units to reach maturity each year varied among the grass species simulated. We used 1800 heat units for the native species and 900 for coastal bermudagrass and bahiagrass.

\section{RESULTS}

\section{Parameter Derivation}

The plant parameters reported herein provide guidance for deciding which are most critical for describing growth of these improved and native species. By using the same experimental techniques on the same or similar sites for all species, we can readily determine how these parameters differ among improved and native species.

An LAI value of 2.2 seemed to be a reasonable average for seasonal maximum (LAImx) for coastal bermudagrass and bahiagrass (Tables 6 and 7). For coastal bermudagrass, LAImx values ranged from 1.2 for the regrowth in 1999 to 5.5 for the main growth period in 1999. The mean LAImx for all growing seasons was $2.86 \pm 1.53$ (mean $\pm \mathrm{SD})$. Without the largest value, the mean LAImx was $2.19 \pm 0.34$. For bahiagrass, the mean LAImx was $2.21 \pm 0.67$.

For the native grasses (Tables 8 and 9), blue grama had the smallest LAImx values. The ranking of species for increasing LAImx was little bluestem, buffalograss, sideoats grama, and switchgrass. For model applications, LAImx values were close to 0.6 for blue grama, 0.8 for little bluestem, 1.8 for buffalograss and sideoats grama, and 6.1 for switchgrass.

Table 6. Coastal bermudagrass leaf area indices (LAI) and light extinction coefficients $(k)$ for Beer's law at Temple, TX and Maysfield, TX. Italic numbers are maximum LAI values for each season.

\begin{tabular}{|c|c|c|c|}
\hline \multicolumn{2}{|c|}{ Temple } & \multicolumn{2}{|c|}{ Maysfield } \\
\hline DOY $\dagger$ (year) & Mean $\leftarrow \pm$ SD & DOY (year) & Mean $\div \pm$ SD \\
\hline 113 (1998) & & 300 (2004) & \\
\hline LAI & $\mathbf{0 . 8 1} \pm \mathbf{0 . 1 0}$ & LAI & $0.59 \pm 0.05$ \\
\hline$k$ & $1.81 \pm 0.11$ & $\boldsymbol{k}$ & $1.42 \pm 0.07$ \\
\hline 148 (1998) & & 312 (2004) & \\
\hline LAI & $2.51 \pm 0.19$ & LAI & $0.51 \pm 0.05$ \\
\hline$k$ & $0.80 \pm 0.08$ & $k$ & $1.64 \pm 0.04$ \\
\hline 337 (1998) & & 137 (2005) & \\
\hline LAI & $1.22 \pm \mathbf{0 . 5 7}$ & LAI & $0.10 \pm 0.04$ \\
\hline$k$ & $1.14 \pm 0.82$ & $\boldsymbol{k}$ & $0.83 \pm 0.61$ \\
\hline 96 (1999) & & 157 (2005) & \\
\hline LAI & $0.42 \pm 0.22$ & LAI & $1.76 \pm 0.67$ \\
\hline $\boldsymbol{k}$ & $1.03 \pm 0.28$ & $k$ & $0.67 \pm 0.14$ \\
\hline 112 (1999) & & $171(2005)$ & \\
\hline LAI & $1.30 \pm 0.47$ & LAI & $1.80 \pm 0.54$ \\
\hline$k$ & $0.92 \pm 0.41$ & $\boldsymbol{k}$ & $\mathbf{0 . 7 7} \pm \mathbf{0 . 2 5}$ \\
\hline 140 (1999) & & 182 (2005) & \\
\hline LAI & $5.55 \pm 2.32$ & LAI & $1.05 \pm 0.31$ \\
\hline$k$ & $0.84 \pm 0.31$ & $k$ & $1.13 \pm 0.74$ \\
\hline 169 (1999) & & $206(2005)$ & \\
\hline LAI & $0.27 \pm 0.12$ & LAI & $\mathbf{0 . 7 0} \pm \mathbf{0 . 1 8}$ \\
\hline$k$ & $1.67 \pm 0.60$ & $k$ & $1.01 \pm 0.21$ \\
\hline \multicolumn{4}{|l|}{179 (1999) } \\
\hline LAI & $0.50 \pm \mathbf{0 . 0 6}$ & & \\
\hline $\boldsymbol{k}$ & $1.64 \pm 0.34$ & & \\
\hline \multicolumn{4}{|l|}{201 (1999) } \\
\hline LAI & $1.22 \pm 0.18$ & & \\
\hline \multirow{2}{*}{\multicolumn{4}{|c|}{$107(2000)$}} \\
\hline & & & \\
\hline LAI & $0.49 \pm 0.39$ & & \\
\hline $\boldsymbol{k}$ & $1.81 \pm 0.57$ & & \\
\hline \multicolumn{4}{|l|}{$128(2000)$} \\
\hline LAI & $1.64 \pm 0.35$ & & \\
\hline$k$ & $\mathbf{1 . 0 3} \pm \mathbf{0 . 1 7}$ & & \\
\hline \multicolumn{4}{|l|}{$150(2000)$} \\
\hline LAI & $2.42 \pm 0.29$ & & \\
\hline $\boldsymbol{k}$ & $0.73 \pm 0.16$ & & \\
\hline \multicolumn{4}{|l|}{$164(2000)$} \\
\hline LAI & $1.93 \pm \mathbf{0 . 5 5}$ & & \\
\hline $\boldsymbol{k}$ & $1.14 \pm 0.25$ & & \\
\hline \multicolumn{4}{|l|}{$161(2003)$} \\
\hline LAI & $1.65 \pm 0.17$ & & \\
\hline \multirow{2}{*}{\multicolumn{4}{|c|}{$171(2003)$}} \\
\hline & & & \\
\hline LAI & $0.47 \pm 0.13$ & & \\
\hline$k$ & $\mathbf{1 . 1 0} \pm \mathbf{0 . 2 2}$ & & \\
\hline \multicolumn{4}{|l|}{183 (2003) } \\
\hline LAI & $1.35 \pm 0.20$ & & \\
\hline $\boldsymbol{k}$ & $\mathbf{0 . 9 8} \pm \mathbf{0 . 1 9}$ & & \\
\hline \multicolumn{4}{|l|}{205 (2003) } \\
\hline LAI & $1.65 \pm 0.25$ & & \\
\hline $\boldsymbol{k}$ & $1.05 \pm 0.10$ & & \\
\hline \multicolumn{4}{|l|}{174 (2005) } \\
\hline LAI & $1.39 \pm 0.35$ & & \\
\hline$k$ & $0.67 \pm 0.08$ & & \\
\hline \multicolumn{4}{|l|}{215 (2005) } \\
\hline LAI & $2.01 \pm 0.21$ & & \\
\hline $\boldsymbol{k}$ & $0.92 \pm 0.02$ & & \\
\hline
\end{tabular}

$\uparrow$ DOY, day of year.

+ Mean $k \pm \mathrm{SD}=1.10 \pm \mathbf{0 . 3 5}, n=26$ dates. Mean LAImx $\pm \mathrm{SD}=2.86 \pm$ 1.53. Without largest value, mean LAImx $=2.19 \pm 0.34$. 
Table 7. Bahiagrass leaf area indices (LAI) and light extinction coefficients $(k)$ for Beer's law at Temple, TX, and Maysfield, TX. Italic numbers are maximum LAI values for each season.

\begin{tabular}{|c|c|c|c|}
\hline \multicolumn{2}{|c|}{ Wills Point } & \multicolumn{2}{|c|}{ Maysfield } \\
\hline DOY $\dagger$ (year) & Mean $\neq \pm$ SD & DOY (year) & Mean $\neq \pm$ SD \\
\hline 85 (2003) & & 300 (2004) & \\
\hline LAI & $0.25 \pm 0.18$ & LAI & $0.23 \pm 0.06$ \\
\hline $\boldsymbol{k}$ & $1.79 \pm \mathbf{1 3 . 4 3}$ & & $1.66 \pm 0.57$ \\
\hline $100(2003)$ & & 312 (2004) & \\
\hline LAI & $\mathbf{0 . 3 8} \pm \mathbf{0 . 1 1}$ & LAI & $0.52 \pm 0.10$ \\
\hline$k$ & $1.77 \pm \mathbf{0 . 4 1}$ & $k$ & $0.91 \pm 0.34$ \\
\hline $176(2003)$ & & $137(2005)$ & \\
\hline LAI & $2.64 \pm 0.78$ & LAI & $\mathbf{0 . 2 5} \pm \mathbf{0 . 0 8}$ \\
\hline$k$ & $1.09 \pm 0.29$ & $k$ & $\mathbf{0 . 8 4} \pm \mathbf{0 . 4 5}$ \\
\hline $190(2003)$ & & 157 (2005) & \\
\hline LAI & $0.86 \pm 0.26$ & LAI & $1.25 \pm 0.18$ \\
\hline$k$ & $0.87 \pm 0.41$ & $k$ & $\mathbf{0 . 5 8} \pm \mathbf{0 . 1 3}$ \\
\hline $204(2003)$ & & 171 (2005) & \\
\hline LAI & $1.72 \pm \mathbf{0 . 3 1}$ & LAI & $1.19 \pm 0.22$ \\
\hline$k$ & $\mathbf{0 . 5 9} \pm \mathbf{0 . 1 0}$ & $k$ & $0.58 \pm 0.19$ \\
\hline $237(2003)$ & & $182(2005)$ & \\
\hline LAI & $1.46 \pm \mathbf{0 . 3 8}$ & LAI & $1.05 \pm 0.76$ \\
\hline$k$ & $0.98 \pm 0.321$ & $\boldsymbol{k}$ & $0.96 \pm 0.12$ \\
\hline 111 (2004) & & 206 (2005) & \\
\hline LAI & $0.56 \pm \mathbf{0 . 0 6}$ & LAI & $0.57 \pm 0.05$ \\
\hline$k$ & $\mathbf{1 . 4 2} \pm \mathbf{0 . 3 6}$ & $k$ & $\mathbf{0 . 6 9} \pm \mathbf{0 . 1 0}$ \\
\hline \multicolumn{4}{|l|}{265 (2004) } \\
\hline LAI & $2.25 \pm 0.51$ & & \\
\hline$k$ & $1.56 \pm 0.23$ & & \\
\hline \multicolumn{4}{|l|}{308 (2004) } \\
\hline LAI & $\mathbf{0 . 3 8} \pm \mathbf{0 . 0 5}$ & & \\
\hline$k$ & $\mathbf{0 . 3 5} \pm \mathbf{0 . 1 4}$ & & \\
\hline \multicolumn{4}{|l|}{$125(2005)$} \\
\hline LAI & $\mathbf{0 . 5 7} \pm \mathbf{0 . 3 3}$ & & \\
\hline$k$ & $1.20 \pm \mathbf{0 . 6 5}$ & & \\
\hline \multicolumn{4}{|l|}{144 (2005) } \\
\hline LAI & $\mathbf{1 . 4 5} \pm \mathbf{0 . 4 5}$ & & \\
\hline$k$ & $1.21 \pm 0.53$ & & \\
\hline \multicolumn{4}{|l|}{158} \\
\hline LAI & $2.14 \pm 0.49$ & & \\
\hline$k$ & $\mathbf{0 . 7 0} \pm \mathbf{0 . 1 8}$ & & \\
\hline \multicolumn{4}{|l|}{$168(2005)$} \\
\hline LAI & $2.69 \pm 0.48$ & & \\
\hline$k$ & $\mathbf{0 . 5 2} \pm 0.07$ & & \\
\hline \multicolumn{4}{|l|}{181 (2005) } \\
\hline LAI & $\mathbf{1 . 5 2} \pm \mathbf{0 . 4 6}$ & & \\
\hline & $\mathbf{0 . 9 5} \pm \mathbf{0 . 2 7}$ & & \\
\hline \multicolumn{4}{|l|}{$210(2005)$} \\
\hline LAI & $0.78 \pm 0.09$ & & \\
\hline$k$ & $\mathbf{0 . 7 8} \pm \mathbf{0 . 1 1}$ & & \\
\hline
\end{tabular}

$\dagger$ DOY, day of year.

$\ddagger$ Mean $k \pm$ SD $=1.00 \pm 0.42 ; n=22$ dates. Mean LAImx \pm SD $=$ $2.21 \pm 0.67$.

Values for $k$ also showed some similarity among grass species. A value of 1.0 to 1.1 seemed to be reasonable for coastal bermudagrass, bahiagrass, and sideoats grama, whereas the switchgrass value seemed to be close to 0.7. Reasonable values for the other grasses were 1.3 for little bluestem, 1.6 for blue grama, and 2.1 for buffalograss.

Radiation use efficiency is the slope of the line for aboveground dry biomass as a function of summed intercepted PAR (see example in Fig. 2). Of the five grasses for which we measured RUE (Tables 10 and 11), coastal bermudagrass had the largest RUE values, followed by buffalograss and bahiagrass. Sideoats grama and blue grama had the lowest values.

Nitrogen concentrations [N] measured throughout the season (Fig. 3) were used to estimate optimum concentrations for plants at each developmental stage. Grass [N] values showed similar patterns of change during the seasons, with three of the five measured species decreasing nonlinearly to near $0.010 \mathrm{~g}$ per g dry biomass by the end of the growing season. Coastal bermudagrass $[\mathrm{N}]$ (Fig. 3a) decreased from about 0.040 to 0.010 g per g dry biomass during the seasons. Bahiagrass $[\mathrm{N}]$ (Fig. 3b) decreased in a similar fashion. Its maximum and minimum values also were near 0.040 and 0.010 . Values for buffalograss [N] (Fig. 3c) began lower but did not decrease to such a low concentration; it decreased from 0.036 to 0.017 . Sideoats grama [N] (Fig. 3d) decreased from 0.027 to 0.010 . Blue grama [N] (Fig. 3e) decreased from about 0.025 to 0.020 . Thus, initial values for $[\mathrm{N}]$ were greatest for coastal and bahiagrass and lowest for sideoats grama and blue grama. Estimates for lateseason [N] were near 0.010 for three of the five species, with buffalograss and blue grama having the greatest values for late season $[\mathrm{N}]$.

The direct comparison of the fitted lines for $[\mathrm{N}]$ (Fig. 3f) showed how coastal bermuda's initial high [N] sampling occurred on a later date than for bahiagrass. Coastal bermuda growth began later in the spring than for bahiagrass, so the first sampling was later. The curves for the three native species were more level. The curves for coastal bermuda, bahiagrass, and sideoats grama were similar after about Day 150.

\section{Model Evaluation}

The ALMANAC model reasonably simulated the aboveground dry biomass production means and SDs for range sites, coastal bermudagrass, and bahiagrass (Table 12). For coastal bermudagrass, the simulated mean $\pm \mathrm{SD}$ was $6.3 \pm 2.6 \mathrm{Mg} \mathrm{ha}^{-1}$, as compared with $6.3 \pm 2.4$ as reported by NRCS. For bahiagrass, the simulated values were $6.3 \pm 1.2$, and the NRCS reported values were $6.2 \pm 1.4$. For range sites, simulated values and NRCS values were $4.3 \pm 1.5$.

Each set of simulations (coastal bermudagrass, bahiagrass, and range sites) failed to show consistent bias at low, medium, or high yields. The simulated results were split into three groups based on NRCS reported yields. For coastal bermudagrass, these groups were 3 to $5 \mathrm{Mg}$ $\mathrm{ha}^{-1}, 6$ to $8 \mathrm{Mg} \mathrm{ha}^{-1}$, and $9 \mathrm{Mg} \mathrm{ha}^{-1}$ and greater. Because of the nature of the NRCS yield data, being means of multiple years, we used the mean simulated yield/ reported yield ratios for comparisons. The low group, with 15 soil/county combinations, had a mean simulated yield/reported yield ratio of 1.06 . The mean ratio for the mid range of yields was $0.96(n=12)$. The highest yielding group had a ratio of $1.03(n=11)$. For bahiagrass, the three groupings were 2 to $5 \mathrm{Mg} \mathrm{ha}^{-1}(n=4)$, 6 to $7 \mathrm{Mg} \mathrm{ha}^{-1}(n=4)$, and $8 \mathrm{Mg} \mathrm{ha}^{-1}$ and greater $(n=2)$. The mean simulated yield/reported yield ratios were 1.08, 1.06 , and 0.89 , respectively.

For range sites, the three groupings were for 2 to $3 \mathrm{Mg}$ $\mathrm{ha}^{-1}(n=5), 4$ to $5 \mathrm{Mg} \mathrm{ha}^{-1}(n=12)$, and $6 \mathrm{Mg} \mathrm{ha}^{-1}$ and greater $(n=7)$. Simulated/reported ratios were 1.04 , 1.07 , and 0.95 , respectively.

The relative rankings between range and coastal bermudagrass simulated yields agreed with the rankings of NRCS-reported yields in most cases. Of the 24 soil/ county combinations with range and coastal bermudagrass yields reported, the relative rankings of range/ 
Table 8. Blue grama, little bluestem, and buffalograss leaf indices (LAI) and light extinction coefficients (k) for Beer's law for at Temple, TX. Italic numbers are maximum LAI values for each season.

\begin{tabular}{ll}
\hline DOY $\dagger(1998)$ & Mean \pm SD \\
\hline & \\
89 & \\
$\quad$ LAI & $0.06 \pm 0.05$ \\
$k$ & $1.95 \pm 0.98$ \\
119 & \\
LAI & $0.16 \pm 0.06$ \\
$k$ & $0.73 \pm 0.39$ \\
146 & \\
LAI \\
$k$ & $0.14 \pm 0.04$ \\
& $1.23 \pm 0.35$
\end{tabular}

$\begin{array}{ll}\frac{\text { DOY (1998) }}{92} & \\ \underset{\text { LAI }}{k} & 0.06 \pm 0.03 \\ 203 & 1.68 \pm 1.09 \\ \quad \text { LAI } & 0.32 \pm 0.11 \\ k & 0.83 \pm 0.23\end{array}$

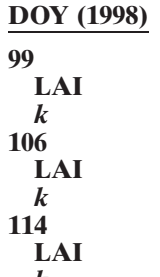

$\boldsymbol{k}$

$\dagger$ DOY, day of year.

\$ For blue grama: mean $k \pm S D=1.62 \pm 0.58, n=12$ dates; mean LAImx \pm SD $=0.59 \pm 0.58$; without 1999 , mean LAImx $=0.26 \pm 0.14$.

$\S$ For little bluestem: mean $k \pm S D=1.34 \pm 0.70, n=10$ dates; mean LAImx \pm SD $=0.76 \pm 0.74$; without 2000, mean LAImx $=0.33 \pm 0.01$.

II For buffalograss: mean $k \pm S D=2.13 \pm 0.58, n=7$ dates; mean LAImx \pm SD (1998 and 1999) $=1.77 \pm 0.71$.

coastal bermudagrass for simulated yields agreed with NRCS yields in 19 cases. For these 19 cases, coastal bermudagrass yields exceeded range site yields in 16 cases and were less than range site yields in two cases and similar to the range site yield for one case. Three of the five cases where rankings differed had NRCS coastal bermudagrass yields less than NRCS range site yields.

For bahiagrass and coastal bermudagrass, results were even more promising. Of the $10 \mathrm{soil} /$ county combinations with bahiagrass, the relative ranking of bahiagrass/ coastal bermudagrass simulated yields agreed with NRCS rankings in all cases. Coastal bermudagrass yields were greater than bahiagrass yields in eight of these cases and nearly the same in two.

For the Eagle Lake simulations, ALMANAC's simulated biomass yields were similar to the reported biomass for the different $\mathrm{N}$ treatments for both years (Fig. 4 and 5). The highest applied $\mathrm{N}$ treatment had simulated/ reported ratios of 1.00 and 1.07 for bahiagrass in the $2 \mathrm{yr}$. For coastal bermudagrass, these ratios were 0.90 and 0.91. For the zero applied $\mathrm{N}$ treatments, the yield ratios were 0.70 and 0.75 for bahiagrass and 0.76 and 0.68 for coastal bermudagrass. Although simulated and reported responses had somewhat similar shapes, the simulated yields tended to have plateaus with the high $\mathrm{N}$ treatments, whereas the reported yields did not.

\section{DISCUSSION}

The results reported herein provide important values for simulating these common grass species in the southern USA. The previously published values on switchgrass and sideoats grama described below are from Kiniry et al. (1999). Values for these species described in this article show promise for refinement of those parameters. Values for coastal bermudagrass, bahiagrass, buffalograss, little bluestem, and blue grama will help extend the modeling of grasslands and pastures to different areas and different management scenarios.

When examining values of $k$ and LAI, certain patterns emerge within and among species. We learned that species with the largest LAImx values tended to 
Table 9. Sideoats grama and switchgrass leaf area indices (LAI) and light extinction coefficients ( $k$ ) for Beer's law for at Temple, TX. Italic numbers are maximum LAI values for each season.

\begin{tabular}{|c|c|c|c|c|c|}
\hline DOY (1998) & mean \pm SD & DOY (1999) & mean \pm SD & DOY (2000) & mean $\pm \mathbf{S D}$ \\
\hline \multicolumn{6}{|c|}{$\underline{\text { Sideoats grama } \dagger}$} \\
\hline 89 & & 96 & & 107 & \\
\hline LAI & $\mathbf{0 . 3 3} \pm \mathbf{0 . 2 5}$ & LAI & $0.36 \pm 0.05$ & LAI & $1.39 \pm \mathbf{0 . 4 5}$ \\
\hline$k$ & $1.38 \pm 0.97$ & $k$ & $2.07 \pm 0.74$ & $k$ & $\mathbf{0 . 9 2} \pm \mathbf{0 . 2 3}$ \\
\hline 119 & & 111 & & 128 & \\
\hline LAI & $1.45 \pm 0.26$ & LAI & $0.68 \pm 0.34$ & LAI & $2.27 \pm 1.67$ \\
\hline$k$ & $\mathbf{0 . 5 8} \pm \mathbf{0 . 0 7}$ & $k$ & $1.11 \pm 0.59$ & $k$ & $\mathbf{0 . 8 6} \pm \mathbf{0 . 2 5}$ \\
\hline 146 & & 140 & & 150 & \\
\hline LAI & $0.46 \pm 0.10$ & LAI & $1.79 \pm 0.94$ & LAI & $1.72 \pm \mathbf{0 . 7 6}$ \\
\hline \multirow{27}{*}{$\boldsymbol{k}$} & $\mathbf{0 . 5 8} \pm \mathbf{0 . 0 6}$ & $k$ & $0.98 \pm 0.38$ & $k$ & $\mathbf{1 . 1 8} \pm \mathbf{0 . 1 4}$ \\
\hline & & 169 & & 164 & \\
\hline & & LAI & $0.29 \pm 0.08$ & LAI & $1.62 \pm 0.50$ \\
\hline & & $k$ & $1.87 \pm 0.74$ & $k$ & $1.23 \pm \mathbf{0 . 6 5}$ \\
\hline & & 179 & & & \\
\hline & & LAI & $0.52 \pm 0.10$ & & \\
\hline & & $k$ & $1.04 \pm 0.19$ & & \\
\hline & & 201 & & & \\
\hline & & LAI & $1.23 \pm 0.31$ & & \\
\hline & & $\boldsymbol{k}$ & $0.69 \pm 0.08$ & & \\
\hline & & \multicolumn{2}{|c|}{$\underline{\text { Switchgrass }}$} & & \\
\hline & & DOY (1999) & mean \pm SD & $\underline{\text { DOY (2000) }}$ & mean $\pm \mathbf{S D}$ \\
\hline & & 96 & & 107 & \\
\hline & & LAI & $1.60 \pm 0.62$ & LAI & $\mathbf{3 . 0 0} \pm \mathbf{1 . 5 6}$ \\
\hline & & $k$ & $0.91 \pm 0.66$ & $k$ & $0.74 \pm \mathbf{0 . 3 4}$ \\
\hline & & 112 & & 128 & \\
\hline & & LAI & $3.96 \pm 1.39$ & LAI & $6.12 \pm 2.56$ \\
\hline & & $k$ & $0.53 \pm 0.12$ & $k$ & $0.49 \pm 0.29$ \\
\hline & & 140 & & 150 & \\
\hline & & LAI & $6.07 \pm 2.69$ & LAI & $\mathbf{3 . 0 0} \pm \mathbf{1 . 5 6}$ \\
\hline & & $k$ & $1.04 \pm \mathbf{0 . 8 3}$ & $k$ & $\mathbf{0 . 7 4} \pm \mathbf{0 . 3 4}$ \\
\hline & & 179 & & 164 & \\
\hline & & LAI & $0.94 \pm 0.19$ & LAI & $5.67 \pm 1.74$ \\
\hline & & $k$ & $0.78 \pm 0.12$ & $k$ & $\mathbf{0 . 3 6} \pm \mathbf{0 . 1 1}$ \\
\hline & & \multicolumn{2}{|l|}{202} & & \\
\hline & & LAI & $2.20 \pm 0.37$ & & \\
\hline & & $k$ & $0.63 \pm 0.11$ & & \\
\hline
\end{tabular}

+ For sideoats grama: mean $\mathbf{k} \pm \mathrm{SD}=1.11+0.45, \mathrm{n}=13$ dates; mean LAImx $\pm \mathrm{SD}=1.84 \pm 0.41$.

+ For switchgrass: mean $\mathrm{k} \pm \mathrm{SD}=\mathbf{0 . 6 9}+\mathbf{0 . 2 1}, \mathrm{n}=9$ dates; mean $\mathrm{LAImx} \pm \mathrm{SD}=\mathbf{6 . 1 0} \pm \mathbf{0 . 0 4}$.

have the lowest $k$ values. Switchgrass had the greatest LAImx (near 6.0) and the smallest mean $k$ (0.69). The two species with the smallest LAImx values, little bluestem and blue grama, had some of the greatest mean $k$ values (1.34 and 1.62). Three intermediate LAI species, coastal bermudagrass, bahiagrass, and sideoats grama, had intermediate mean $k$ values ranging from 1.0 to 1.11. Buffalograss was unusual in that it had an intermediate mean LAImx value but had the greatest mean $k$ (2.13).

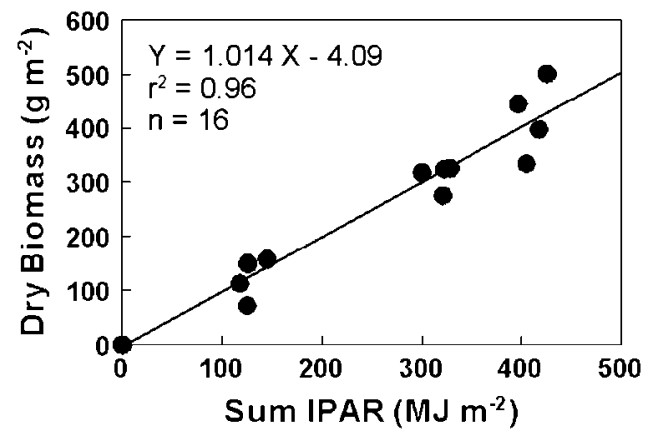

Fig. 2. An example demonstrating how radiation use efficiency (RUE) is calculated. This is the aboveground dry biomass of coastal bermudagrass at Temple, TX in 2000 as a function of summed intercepted photosynthetically active radiation (IPAR). The slope is the RUE.
The highest $k$ values sometimes occur at low LAI values early in the season because at that time plants have less mutual shading among leaves and more horizontal leaf orientation, leading to more efficient light interception. To test for unusually high $k$ values, we calculated a threshold $k$ value for each species as the sum of the mean and 1 SD. We chose $1 \mathrm{SD}$ as the threshold to standardize the criterion while taking into account the variability in the results. These $k$ thresholds were 1.45 for

Table 10. Coastal bermudagrass and bahiagrass radiation use efficiency (RUE) (g of dry biomass per MJ intercepted photosynthetically active radiation) for two locations in Texas.

\begin{tabular}{|c|c|c|c|c|}
\hline Location & Year & RUE & $n$ & $r^{2}$ \\
\hline \multicolumn{5}{|c|}{ Coastal bermudagrass $\dagger$} \\
\hline Temple & 1999 & 1.88 & 12 & 0.97 \\
\hline Temple & 2000 & 1.01 & 16 & 0.96 \\
\hline Temple & 2003 & 1.08 & 16 & 0.88 \\
\hline Maysfield & 2005 & 1.56 & 15 & 0.74 \\
\hline Maysfield (regrowth) & 2005 & 2.00 & 10 & 0.79 \\
\hline \multicolumn{5}{|c|}{$\underline{\text { Bahiagrass } \ddagger}$} \\
\hline Wills Pt. & 2003 & 0.77 & 4 & 0.98 \\
\hline Wills Pt. (regrowth) & 2003 & 1.71 & 3 & 0.96 \\
\hline Wills Pt. & 2005 & 0.64 & 17 & 0.88 \\
\hline Wills Pt. (regrowth) & 2005 & 2.00 & 10 & 0.91 \\
\hline Maysfield & 2005 & 1.12 & 15 & 0.92 \\
\hline
\end{tabular}

$\dagger$ For coastal bermudagrass: mean, 1.50; SD, 0.46; mean of top two, 1.94 . $\uparrow$ For bahiagrass: mean, 1.25; SD, 0.59; mean of top two, 1.855 . 
Table 11. Sideoats grama, buffalograss, and blue grama radiation use efficiency (RUE) ( $g$ of dry biomass per MJ intercepted PAR) for 3 yr at Temple, TX.

\begin{tabular}{llrl}
\hline Year & RUE & $n$ & $r^{2}$ \\
\hline & Sideoats grama & & \\
1998 & 1.23 & 9 & 0.94 \\
1999 & 0.96 & 12 & 0.75 \\
$2000 \quad 0.67$ & 16 & 0.59 \\
Mean (SD) & $0.95(0.28)$ & & \\
Mean of top 2 & 1.10 & & \\
& Buffalograss & & \\
1998 & 1.30 & 15 & 0.81 \\
1999 & 1.42 & 12 & 0.89 \\
2000 & 1.43 & 8 & 0.89 \\
Mean (SD) & $1.38(0.07)$ & & \\
Mean of top 2 & 1.43 & & \\
& Blue grama & & \\
1998 & 0.72 & 11 & 0.89 \\
1999 & 0.46 & 11 & 0.44 \\
$2000 \quad$ Mean (SD) & 0.53 & 16 & 0.72 \\
Mean of top 2 & $0.63(0.14)$ & & \\
\hline
\end{tabular}

coastal bermudagrass, 1.42 for bahiagrass, 2.04 for little bluestem, 2.20 for blue grama, 1.56 for sideoats grama, 2.71 for buffalograss, and 0.90 for switchgrass. For coastal bermudagrass, $k$ exceeded the threshold in five of eight cases when LAI was less than 1.0. For bahiagrass, $k$ exceeded the threshold in only four of nine cases

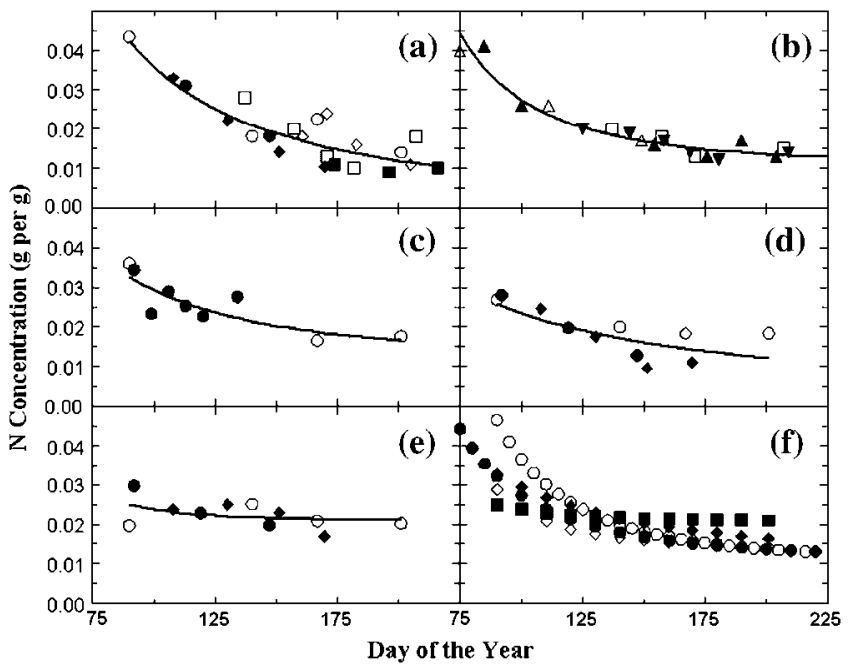

Fig. 3. Nitrogen concentrations on different dates for (a) coastal bermudagrass, (b) Pensacola bahiagrass, (c) buffalograss, (d) sideoats grama, and (e) blue grama. The regressions are compared in (f). "T" designates the Temple, TX location, " $M$ " designates the Maysfield, TX location, and "W" designates Wills Point, TX location. Symbols represent different years at each location as T 1998 (solid circles), T 1999 (open circles), T 2000 (solid diamond), T 2003 (open diamond), T 2005 (solid square), M 2005 (open square), W 2003 (solid triangle), W 2004 (open triangle), and W 2005 (solid squares). The fit equations (indicated by the solid lines) are coastal bermudagrass: $\left.\mathrm{Y}=0.0010616+36649.5 \mathrm{X}^{-3.0745}\right) n=22 ; r^{2}=$ 0.78); bahiagrass: $\mathrm{Y}=0.00107+1389.64 \mathrm{X}^{-2.4625}\left(n=21 ; r^{2}=\right.$ 0.93); buffalograss: $Y=0.0095+19.77 X^{-1.500}\left(n=10 ; r^{2}=0.72\right)$; sideoats grama: $\mathrm{Y}=0.0136+309500 \mathrm{X}^{-3.742}\left(n=11 ; r^{2}=0.68\right)$; blue grama: $\mathrm{Y}=0.0206+8876.6 \mathrm{X}^{-3.227}\left(n=11 ; r^{2}=0.17\right)$. For (f), regression symbols are coastal bermudagrass (open circle), bahiagrass (solid circle), buffalograss (solid diamond), sideoats grama (open diamond), and blue grama (solid squares).
Table 12. Average annual grass productivity simulated with the ALMANAC model for $30 \mathrm{yr}$ and reported in the NRCS Web Soil Survey.

\begin{tabular}{|c|c|c|c|c|c|}
\hline \multirow[b]{2}{*}{ Counties } & \multirow[b]{2}{*}{ Soils } & & \multicolumn{3}{|c|}{ Yields } \\
\hline & & & Range & $\begin{array}{c}\text { Coastal } \\
\text { Bermudagrass }\end{array}$ & Bahiagrass \\
\hline & & & & $-\mathrm{Mg} \mathrm{ha}^{-1}$ & \\
\hline \multirow{6}{*}{$\begin{array}{l}\text { Brown } \\
\quad \text { \& Mills }\end{array}$} & Speck & simulated & 4.9 & 3.7 & _- \\
\hline & & NRCS & 5.0 & 3.5 & - \\
\hline & Frio & simulated & 4.0 & 3.9 & - \\
\hline & & NRCS & 4.0 & 7.1 & - \\
\hline & Bolar & simulated & 3.2 & 4.0 & - \\
\hline & & NRCS & 3.0 & 5.0 & - \\
\hline \multirow[t]{6}{*}{ Coryell } & Doss & simulated & 2.3 & 3.6 & - \\
\hline & & NRCS & 3.0 & 4.0 & - \\
\hline & Lewisville & simulated & 4.4 & 6.5 & - \\
\hline & & NRCS & 5.5 & 7.6 & - \\
\hline & Topsey & simulated & 6.2 & 3.9 & - \\
\hline & & NRCS & 5.1 & 4.0 & - \\
\hline \multirow[t]{6}{*}{ Denton } & Speck & simulated & 2.3 & 3.8 & - \\
\hline & & NRCS & 3.0 & 3.5 & - \\
\hline & Heiden & simulated & 6.0 & 6.7 & - \\
\hline & & NRCS & 6.1 & 7.1 & - \\
\hline & Sanger & simulated & 5.7 & 6.9 & - \\
\hline & & NRCS & 5.1 & 6.6 & - \\
\hline \multirow[t]{6}{*}{ Falls } & Ferris & simulated & 4.1 & 4.5 & - \\
\hline & & NRCS & 5.6 & 3.5 & _- \\
\hline & Ships & simulated & 6.0 & 6.0 & - \\
\hline & & NRCS & 6.1 & 6.1 & _- \\
\hline & Wilson & simulated & 5.5 & 6.4 & - \\
\hline & & NRCS & 4.5 & 6.1 & _- \\
\hline \multirow{6}{*}{ Grimes } & Zulch & simulated & 4.3 & 6.5 & 5.5 \\
\hline & & NRCS & 4.0 & 6.1 & 5.1 \\
\hline & Nahatche & simulated & 4.8 & 9.2 & 8.1 \\
\hline & & NRCS & 4.5 & 9.1 & 7.1 \\
\hline & Shiro & simulated & 4.1 & 5.1 & 5.0 \\
\hline & & NRCS & 4.2 & 5.2 & 4.0 \\
\hline \multirow{6}{*}{$\begin{array}{l}\text { Lamar } \\
\text { \& Delta }\end{array}$} & Annona & simulated & - & 5.7 & 5.4 \\
\hline & & NRCS & _- & 5.1 & 5.1 \\
\hline & Freestone & simulated & - & 8.9 & 7.5 \\
\hline & & NRCS & - & 9.1 & 8.1 \\
\hline & Crockett & simulated & 5.5 & 6.9 & - \\
\hline & & NRCS & 5.1 & 6.6 & - \\
\hline Medina & Webb & simulated & 3.2 & 4.3 & _- \\
\hline (dryland) & & NRCS & 2.8 & 3.0 & - \\
\hline & Victoria & simulated & 3.0 & - & _- \\
\hline & & NRCS & 4.0 & - & - \\
\hline & Knippa & simulated & 2.7 & 4.0 & _- \\
\hline & & NRCS & 3.2 & 5.0 & - \\
\hline Medina & Webb & simulated & - & 12.3 & - \\
\hline (irrigated) & & NRCS & - & 10.1 & - \\
\hline & Victoria & simulated & - & 10.1 & - \\
\hline & & NRCS & - & 12.1 & - \\
\hline & Knippa & simulated & - & 12.1 & - \\
\hline & & NRCS & - & 9.1 & - \\
\hline Smith & Cuthbert & simulated & - & 6.0 & 5.9 \\
\hline & & NRCS & - & 7.1 & 6.1 \\
\hline & Oakwood & simulated & - & 7.9 & 6.8 \\
\hline & & NRCS & - & 9.1 & 8.1 \\
\hline & Wolfpen & simulated & - & 7.3 & 6.4 \\
\hline & & NRCS & - & 8.1 & 6.1 \\
\hline Uvalde & Castroville & simulated & 2.1 & 4.3 & - \\
\hline (dryland) & & NRCS & 3.2 & 4.0 & - \\
\hline & Caid & simulated & 2.5 & 4.5 & - \\
\hline & & NRCS & 3.2 & 3.0 & - \\
\hline & Knippa & simulated & 3.5 & 3.9 & - \\
\hline & & NRCS & 3.2 & 5.0 & - \\
\hline Uvalde & Castroville & simulated & -2 & 11.4 & - \\
\hline (irrigated) & & NRCS & - & 10.1 & - \\
\hline & Caid & simulated & - & 11.3 & - \\
\hline & & NRCS & - & 12.1 & - \\
\hline & Knippa & simulated & - & 11.1 & - \\
\hline & & NRCS & - & 9.1 & - \\
\hline VanZandt & Bazette & simulated & - & 5.0 & 4.7 \\
\hline & & NRCS & - & 5.1 & 5.0 \\
\hline & Sandow & simulated & - & 8.7 & 7.5 \\
\hline & & NRCS & - & 8.1 & 7.1 \\
\hline & Crockett & simulated & - & 7.2 & - \\
\hline & & NRCS & - & 6.6 & - \\
\hline
\end{tabular}

Continued on next page. 
Table 12. Continued.

\begin{tabular}{|c|c|c|c|c|c|}
\hline \multirow[b]{2}{*}{ Counties } & \multirow[b]{2}{*}{ Soils } & & \multicolumn{3}{|c|}{ Yields } \\
\hline & & & Range & $\begin{array}{c}\text { Coastal } \\
\text { Bermudagrass }\end{array}$ & Bahiagra \\
\hline & & & & - Mg ha $^{-1}$ & \\
\hline \multirow[t]{6}{*}{ Victoria } & Denhawken & simulated & 3.2 & 5.3 & - \\
\hline & & NRCS & 3.5 & 3.0 & - \\
\hline & Dacosta & simulated & 5.4 & 9.2 & - \\
\hline & & NRCS & 5.6 & 10.1 & - \\
\hline & Laewest & simulated & 7.9 & 8.1 & - \\
\hline & & NRCS & 8.1 & 9.1 & - \\
\hline
\end{tabular}

when LAI was less than 1.0. Blue grama, with its much smaller LAI values, had no dates with $k$ greater than its threshold. Sideoats grama had no dates with $k$ larger than the threshold in 1998 and 2000. However, in 1999, the two dates with the lowest LAI values had $k$ values in excess of the threshold. None of the buffalograss $k$ values on the first harvest each year had $k$ values above the threshold. Switchgrass $k$ was above the threshold on the first sampling date in 1999 but not in 2000.

Values of LAImx we obtained for sideoats grama were comparable to those in the previously published study, but those for switchgrass were much lower (near 6), compared with 12 or more in the published study. Both switchgrass values are sufficiently large to intercept nearly all the incident light and allow maximum plant transpiration. For sideoats grama, the previously published values were near 1.6 and 1.7, whereas in this study the values were near 1.8.

Values for extinction coefficient of sideoats grama were also close to the values previously published (Kiniry et al., 1999), whereas switchgrass showed some deviation. The sideoats grama mean $k$ of 1.11 was comparable to the previously published mean of 1.05 . The switchgrass mean $k$ of 0.69 was greater than the previously published mean of 0.33 .

The RUE values were lower than the 4.0 to $5.0 \mathrm{~g} \mathrm{MJ}^{-1}$ previously reported for switchgrass but were similar to the previously reported 1.4 for big bluestem. Radiation use efficiency values for four of the five measured grass species in the present study were between 1.0 and $2.0 \mathrm{~g}$

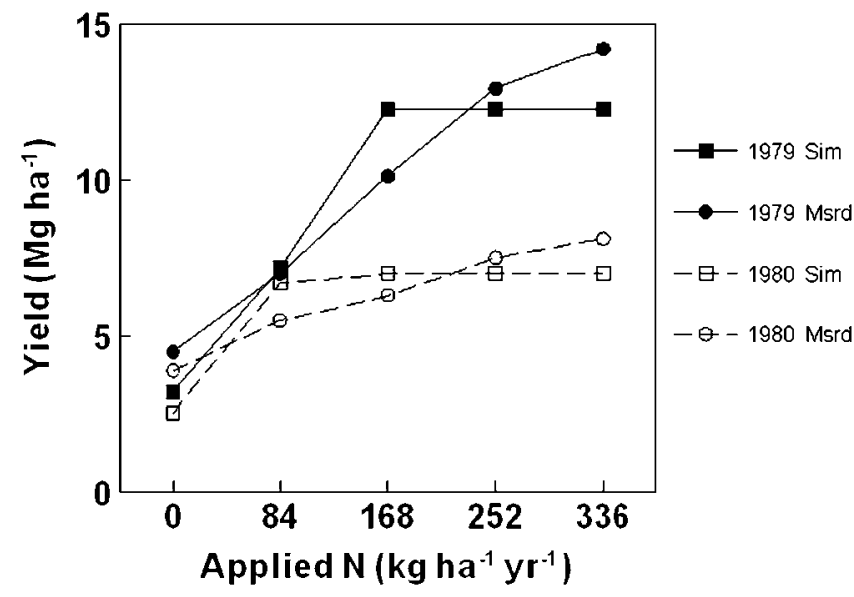

Fig. 4. For coastal bermudagrass, simulated and measured yield responses to applied nitrogen for $2 \mathrm{yr}$ at Eagle Lake, TX. Measured rainfall values were $1444 \mathrm{~mm}$ in 1979 and $817 \mathrm{~mm}$ in 1980 .

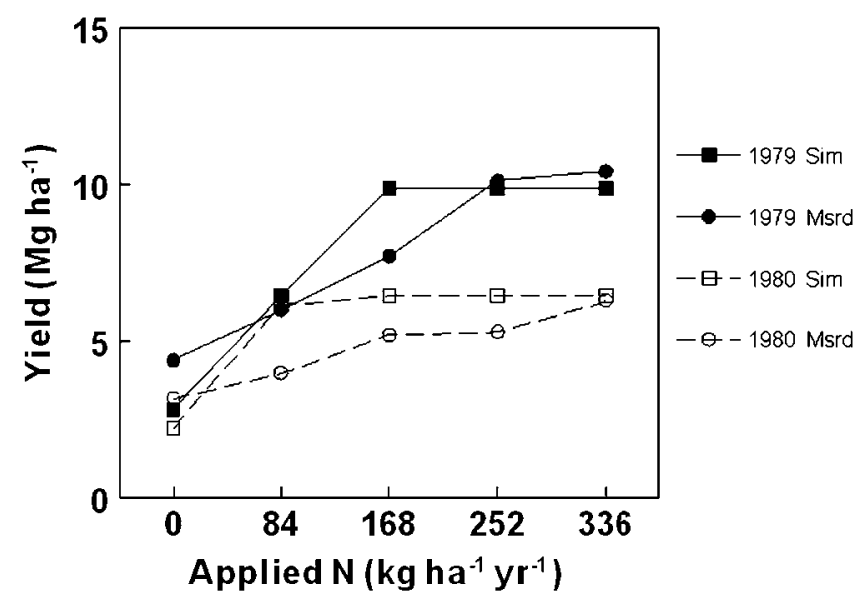

Fig. 5. For bahiagrass, simulated and measured yield responses to applied nitrogen for 2 yr at Eagle Lake, TX. Measured rainfall values were $1444 \mathrm{~mm}$ in 1979 and $817 \mathrm{~mm}$ in 1980 .

$\mathrm{MJ}^{-1}$. For sideoats grama, the mean RUE for the top $2 \mathrm{yr}$ for the present study was the same as previously published $\left(1.1 \mathrm{~g} \mathrm{MJ}^{-1}\right)$. For coastal bermudagrass and bahiagrass, the means for the top $2 \mathrm{yr}$ were near $1.9 \mathrm{~g}$ $\mathrm{MJ}^{-1}$. Corresponding values were 1.43 for buffalograss and 0.63 for blue grama.

The $[\mathrm{N}]$ values give guidance as to reasonable parameters for the various growth stages of the grasses. The nonlinear decreases in $[\mathrm{N}]$ demonstrated how comparisons between coastal and bahiagrass change over the course of the season. Bahiagrass, with its earlier growth, showed rapidly decreasing $[\mathrm{N}]$ before spring growth had begun for coastal. However, initial harvests of bahiagrass and coastal had similar $[\mathrm{N}]$ values, as did the final harvests of each. Initial values near $0.04 \mathrm{~kg} \mathrm{~kg}^{-1}$ seem to be reasonable for coastal bermudagrass, bahiagrass, and buffalograss, whereas values for the other two species were lower. Concentrations decreased to near 0.01 for coastal bermudagrass and bahiagrass. The other three species had final $[\mathrm{N}]$ values near 0.015 to 0.020 .

Based on these results, the ALMANAC model seems to be a realistic tool to simulate the effects of soil type and weather when comparing grass productivity of native grasses to coastal bermudagrass and bahiagrass in diverse regions of Texas. The model also holds promise for simulating these grasses in other areas of the USA. Because it simulates nutrient uptake, canopy cover, and soil erosion, ALMANAC could be used as a realistic tool for comparing nutrient uptake of native and improved grasses. The model's ability to simulate leaf canopy cover should make it a useful tool for comparing the impacts of grazing and hay cutting management on soil erosion for native and improved grasses.

\section{ACKNOWLEDGMENTS}

The authors thank Mr. and Mrs. Bobby J. Neill of Wills Point, TX, for allowing the measurements of bahiagrass on their pasture. The authors also thank Mr. William Pagach of Maysfield, TX, for allowing the measurements of bahiagrass and coastal bermudagrass on his pasture. 


\section{REFERENCES}

Adams, W.E., C.B. Elkins, Jr., and E.R. Beaty. 1966. Rooting habits and moisture use of coastal bermudagrass and common bermudagrass. J. Soil Water Conserv. 21:133-135.

Adjei, M.B., P. Mislevy, and C.Y. Ward. 1980. Response of tropical grasses to stocking rate. Agron. J. 72:863-868.

Agata, W. 1985a. Studies on dry matter production of bahiagrass (Paspalum notatum) sward. I. Characteristics of dry matter production during the regrowth period. p. 1235-1236. In T. Okubo and M. Shiyomi (ed.) Proc. Int. Grassl. Congr. 15th, Kyoto, Japan. 24-31 Aug. 1985. Kyoto, Japan.

Agata, W. 1985b. Studies on dry matter production of bahiagrass (Paspalum notatum) sward: II. Characteristics of $\mathrm{CO}_{2}$ balance and solar energy utilization during the regrowth period. p. 1237-1238. In T. Okubo and M. Shiyomi (ed.) Proc. Int. Grassl. Cong. 15th, Kyoto, Japan. 24-31 Aug. 1985. Kyoto, Japan.

Ashley, D.A., O.L. Bennett, B.D. Doss, and C.E. Scarsbrook. 1965. Effect of nitrogen rate and irrigation on yield and residual nitrogen recovery by warm-season grasses. Agron. J. 57:370-372.

Beaty, E.R., K.H. Tan, R.A. McCreery, and J.D. Powell. 1980. Yield and $\mathrm{N}$ content of closely clipped bahiagrass as affected by $\mathrm{N}$ treatment. Agron. J. 72:56-60.

Boote, K.J., J.W. Jones, and G. Hoogenboom. 1998. Simulation of crop growth: CROPGRO model. p. 651-692. In R.M. Peart and R.B. Curry (ed.) Agricultural systems modeling and simulation. Marcel Dekker, New York.

Burton, G.W., and E.H. DeVane. 1952. Effect of rate and method of applying different sources of nitrogen upon the yield and chemical composition of bermuda grass, Cynodon dactylon (L) Pers., hay. Agron. J. 44:128-132.

Burton, G.W., E.H. DeVane, and R.L. Carter. 1954. Root penetration, distribution and activity in southern grasses measured by yields, drought symptoms, and $\mathrm{P}^{32}$ uptake. Agron. J. 46:229-233.

Evers, G.W. 1985. Forage and nitrogen contributions of arrowleaf and subterranean clovers overseeded on bermudagrass and bahiagrass. Agron. J. 77:960-963.

Holt, E.C., and F.L. Fisher. 1960. Root development of coastal with high nitrogen fertilization. Agron. J. 52:593-596.

Innis, G.S. 1978. Grassland simulation model. Springer-Verlag, New York.

Johnson, C.R., B.A. Reiling, P. Mislevy, and M.B. Hall. 2001. Effects of nitrogen fertilization and harvest date on yield, digestibility, fiber, and protein fractions of tropical grasses. J. Anim. Sci. 79:2439-2448.

Kiniry, J.R., and A.J. Bockholt. 1998. Maize and sorghum simulation in diverse Texas environments. Agron. J. 90:682-687.

Kiniry, J.R., J.R. Williams, R.L. Vanderlip, and J.D. Atwood. 1997. Evaluation of two maize models for nine US locations. Agron. J. 89:421-426.

Kiniry, J.R., M.A. Sanderson, J.R. Williams, C.R. Tischler, M.A. Hussey, W.R. Ocumpaugh, M.C. Read, G. Van Esbroeck, and R.L. Reed. 1996. Simulating Alamo switchgrass with the ALMANAC model. Agron. J. 88:602-606.

Kiniry, J.R. 1994. Radiation-use efficiency and grain yield of maize competing with johnsongrass. Agron. J. 86:554-557.

Kiniry, J.R. 1998. Biomass accumulation and radiation use efficiency of honey mesquite and eastern red cedar. Biomass Bioenergy 15 467-473.

Kiniry, J.R. 2006. A general crop model. p. 1-12. In C.W. Richardson et al. (ed.) Modeling and remote sensing applied to agriculture (U.S. and Mexico). USDA-ARS and INIFAP.

Kiniry, J.R., B. Bean, Y. Xie, and P.-Y. Chen. 2004. Maize yield potential: Critical processes and simulation modeling in a high-yielding environment. Agric. Syst. 82:45-56.

Kiniry, J.R., C.R. Tischler, and G.A. VanEsbroeck. 1999. Radiation use efficiency and leaf $\mathrm{CO}_{2}$ exchange for diverse $\mathrm{C}_{4}$ grasses. Biomass Bioenergy 17:95-112.

Kiniry, J.R., H. Sanchez, J. Greenwade, E. Seidensticker, J.R. Bell, F. Pringle, G. Peacock, Jr., and J. Rives. 2002. Simulating grass productivity on diverse range sites in Texas. J. Soil Water Conserv. $57: 144-150$.
Kiniry, J.R., J.R. Williams, P.W. Gassman, and P. Debaeke. 1992. A general, process-oriented model for two competing plant species. Trans. ASAE 35:801-810.

Kiniry, J.R., K.A. Cassida, M.A. Hussey, J.P. Muir, W.R. Ocumpaugh, J.C. Read, R.L. Reed, M.A. Sanderson, B.C. Venuto, and J.R. Williams. 2005. Switchgrass simulation by the ALMANAC model at diverse sites in the southern US. Biomass Bioenergy 29:419-425.

MacNeil, N.D., J.W. Skiles, and J.D. Hanson. 1985. Sensitivity analysis of a general rangeland model. Ecol. Modell. 29:57-76.

Meek, D.W., J.L. Hatfield, T.A. Howell, S.B. Idso, and R.J. Reginato. 1984. A generalized relationship between photosynthetically active radiation and solar radiation. Agron. J. 76:939-945.

Mislevy, P., and P.H. Everett. 1981. Subtropical grass species response to different irrigation and harvest regimes. Agron. J. 73:601-604.

Monsi, M., and T. Saeki. 1953. Über den Lichtfaktor in den Pflanzengesellschaften und seine Bedeutung für die Stoffproduktion. Jpn. J. Bot. 14:22-52.

Monson, W.G., and G.W. Burton. 1982. Harvest frequency and fertilizer effects on yield, quality, and persistence of eight bermudagrasses. Agron. J. 74:371-374.

Monteith, J.L. 1965. Light distribution and photosynthesis in field crops. Ann. Bot. (Lond.) 29:17-37.

Monteith, J.L. 1969. Light interception and radiative exchange in crop stand. p. 89-111. In J.D. Eastin (ed.) Physiological aspects of crop yield. ASA, Madison, WI.

Morgan, J.A., and R.H. Brown. 1983a. Photosynthesis and growth of bermudagrass swards: I. Carbon dioxide exchange characteristics of swards mowed at weekly and monthly intervals. Crop Sci. 23: 347-352.

Morgan, J.A., and R.H. Brown. 1983b. Photosynthesis and growth of bermudagrass swards: II. Growth patterns as estimated by harvest and gas exchange techniques. Crop Sci. 23:352-356.

Morrison, F.B. 1941. Feeds and feeding. The Morrison Publ. Co. Ithaca, NY.

Overman, A.R., E.A. Angley, and S.R. Wilkinson. 1988. Empirica model of coastal bermudagrass production. Trans. ASAE 31:466-470.

Overman, A.R., E.A. Angley, and S.R. Wilkinson. 1989. A phenomenological model of coastal bermudagrass production. Agric. Syst. 29:137-148.

Pedreira, C.G.S., and R.H. Brown. 1996. Yield of selected and unselected bahiagrass populations at two cutting heights. Crop Sci. 36:134-137.

Pedreira, C.G.S., L.E. Sollenberger, and P. Mislevy. 1999. Productivity and nutritive value of "Florakirk" bermudagrass as affected by grazing management. Agron. J. 91:796-801.

Rymph, S.J., K.J. Boote, A. Irmak, P. Mislevy, and G.W. Evers. 2004. Adapting the CROPGRO model to predict growth and composition of tropical grasses: Developing physiological parameters. Proc. Soil Crop Sci. Soc. Fla. 63:37-51.

Sampaio, E.V.S.B., E.R. Beaty, and D.A. Ashley. 1976. Bahiagrass regrowth and physiological aging. J. Range Manage. 29:316-319.

Shantz, H.L. 1911. Natural vegetation as an indicator of the capabilities of land for crop production in the Great Plains Area. USDA. Bureau of Plant Industries Bull. 201:1-100.

Sperry, T.M. 1935. Root systems in Illinois Prairie. Ecology 16:178-202.

Stout, W.L. 1994. Evaluation of the SPUR model for grasslands of the northeastern United States. Agron. J. 86:1001-1005.

Weaver, J.E. 1954. North American prairie. Johnsen Publ. Co., Lincoln, NE.

Wight, J.R., and J.W. Skiles (ed.). 1987. SPUR, simulation of production and utilization of rangelands: Documentation and user guide. Publ. ARS-63. USDA-ARS, Washington, DC

Wilkinson, S.R., and G.W. Langdale. 1974. Fertility needs of the warmseason grasses. p. 119-145. In D.A. Mays (ed.) Forage fertilization. ASA, CSSA, and SSSA, Madison, WI

Williams, J.R., C.A. Jones, and P.T. Dyke. 1984. A modeling approach to determining the relationship between erosion and soil productivity. Trans. ASAE 27:129-144

Yun, X., J.R. Kiniry, V. Nedbalek, and W.D. Rosenthal. 2001. Maize and sorghum simulations with CERES-Maize, SORKAM, and ALMANAC under water-limiting conditions. Agron. J. 93:1148-1155. 